\title{
Upaya Guru Pendidikan Agama Islam dalam Meningkatkan Kemampuan Membaca Alquran
}

\author{
Salma Jihan Utami ${ }^{1}$, Ahmad Kosasih ${ }^{2}$ \\ jihanutamisalma@gmail.com ${ }^{1}$, ahmadkosasihtanjung@gmail.com ${ }^{2}$ \\ Universitas Negeri Padang ${ }^{1,2}$
}

\begin{tabular}{l}
\hline ARTICLE INFO \\
\hline Article history: \\
Received, 21 October 2021 \\
Revised, 9 November 2021 \\
Accepted, 30 November \\
2021 \\
\hline Keywords: \\
Membaca Alquran, Guru \\
PAI, Siswa
\end{tabular}

\section{Clonflict of Interest:}

None

\section{Funding:}

None

\begin{abstract}
Penelitian ini bertujuan mengetahui upaya guru Pendidikan Agama Islam dalam meningkatkan kemampuan membaca Alquran siswa di SMA Negeri 1 Kota Sungai Penuh. Adapun penelitian ini menggunakan metode kualitatif dengan pendekatan studi lapangan. Lokasi Penelitian di SMA Negeri 1 Kota Sungai Penuh. Pengumpulan data menggunakan metode wawancara dan observasi. Data yang diperoleh kemudian dianalisis dengan reduksi data, penyajian data, dan penarikan kesimpulan, setelah itu digunakan beberapa teknik untuk menguji keabsahan data yaitu perpanjangan keikutsertaan, ketekunan pengamatan, dan triangulasi. Hasil penelitian menunjukkan yaitu: 1) upaya guru dalam meningkatkan kemampuan membaca Alquran siswa yaitu metode menyimak, belajar privat, drill, tadarus Alquran, membaca asmaul husna, membaca surah-surah yang telah dipelajari dan surah-surah pendek, kegiatan jum'at beriman, sabar, telaten, dan guru memberikan motivasi kepada siswa. 2) Faktor pendukung yaitu adanya internet, semangat dan motivasi siswa. Sedangkan faktor penghambat yaitu beragamnya kemampuan siswa, kejenuhan dalam belajar, terbatasnya waktu dalam pembelajaran Alquran serta kurangnya perhatian dari orang tua.
\end{abstract}

Corresponding Author: Salma Jihan Utami, Department Islamic Education Faculty of Social Science Universitas Negeri Padang, Indonesia, Email: jihanutamisalma@gmail.com, Phone: $+6281366459317$

\section{Pendahuluan}

Copyright@ $(2021$, Author(s)

Alquran adalah bentuk kata qa-ra- $a$, sehingga kata Alquran dimengerti oleh setiap orang sebagai nama kitab suci yang mulia. Kalam Allah yang diturunkan kepada nabi Muhammad SAW melalui malaikat jibril (Drajat, 2017: 27). Selain itu, Alquran merupakan kitab suci umat Islam yang diharapkan mampu menjadi pembimbing dan pedoman dalam mengarungi bahtera kehidupan. Di dalam Alquran terkandung nilai dan konsep pemecahan berbagai masalah yang dihadapi manusia, baik masalah keagamaan maupun masalah sosial kemasyarakatan (Nisak, 2019:151).

Guru Pendidikan Agama Islam memiliki peranan yang sangat penting dalam membantu siswa agar mampu membaca Alquran, guru dalam Islam dapat dipahami sebagai orang-orang yang bertanggung jawab terhadap perkembangan siswanya. Dimana tugas seorang guru dalam pandangan islam adalah mendidik yakni dengan mengupayakan perkembangan 
seluruh potensi siswa, baik potensi afektif, kognitif, maupun psikomotorik. Dalam Pembelajaran Agama Islam yang menjadi sumber dari pendidikan agama islam adalah Alquran, karena berisi kandungan ajaran-ajaran yang lengkap tentang keimanan, akhlak mulia, aturan ibadah, hubungan manusia dengan Allah, hubungan manusia dengan manusia, serta segala yang berhubungan dengan kehidupan manusia, karena itulah yang terpenting dalam pendidikan agama adalah membaca dan memahami ayat-ayat Alquran. Sebelum mempelajari dalam memahami ayat-ayat Alquran maka sebaiknya sebagai umat islam harus bisa membaca Alquran sesuai dengan ilmu tajwidnya.

Kemampuan guru Pendidikan Agama Islam dalam melaksanakan tugasnya sebagai guru Pendidikan Agama Islam harus ditingkatkan bukan hanya dalam pengetahuan Agama Islam saja akan tetapi yang utama dalam ketrampilan siswa yaitu kemampuan siswa dalam membaca Alquran sesuai dengan ilmu tajwid yang baik dan benar agar siswa tidak hanya mempunyai pengetahuan tentang dunia saja, akan tetapi pengetahuan untuk akhirat lebih diprioritaskan oeleh guru Pendidikan Agama Islam kepada siswanya.

Hasil observasi yang peneliti dapatkan di SMA Negeri 1 Kota Sungai Penuh, salah satu sekolah menengah atas unggul dalam bidang prestasi akademik, namun sebagian besar siswa masih belum mampu membaca Alquran dengan baik sesuai dengan kaidah bacaan yang benar. Permasalahan lainnya adalah kurangnya semangat dan minat siswa untuk mempelajari cara membaca Alquran dengan baik sesuai dengan ilmu tajwid. Dari wawancara peneliti pada tanggal 19 Desember 2020 dengan salah seorang guru Pendidikan Agama Islam di SMA Negeri 1 Kota Sungai Penuh, diperoleh bahwa "masih terdapat sekitar 60\% dari keseluruhan siswa disekolah yang belum lancar bacaan Alqurannya sesuai ilmu tajwid, dan kurangnya minat siswa untuk mempelajari lebih ilmu tajwid." Di SMA Negeri 1 Kota Sungai Penuh kemampuan guru PAI dalam mengajarkan membaca Alquran kepada siswa masih belum cukup untuk membuat siswa berminat dan mempelajari cara membaca Alquran sesuai dengan ilmu tajwid yang baik dan benar.

Siswa-siswi di SMA Negeri 1 Kota Sungai Penuh ini belajar mengaji Alquran atas kemauan sendiri belajar diluar sekolah atau di TPA/TPQ karena dari sekolah maupun guru pendidikan agama islam di SMA Negeri 1 Kota Sungai Penuh tidak bekerja sama dengan pihak manapun berkaitan dengan pembelajaran Alquran. akan tetapi di dalam pembelajaran pendidikan agama islam di SMA, pembelajaran tentang Alquran hanya terdapat pada materi tajwid seperti contoh, guru pendidikan agama islam yang melakukan tes kemampuan membaca Alquran siswa-siswi.

Alasan peneliti meneliti di SMA Negeri 1 Kota Sungai Penuh mengenai upaya guru PAI dalam meningkatkan kemampuan membaca Alquran yaitu dikarena kelemahan dalam mata pelajaran Pendidikan Agama Islam terutama dari segi membaca Alquran yang sesuai dengan kaidah ilmu tajwid. Berdasarkan masalah yang dipaparkan tersebut, maka peneliti tertarik untuk meneliti apa saja yang dilakukan oleh "Upaya Guru Pendidikan Agama Islam dalam Meningkatkan Kemampuan Membaca Alquran Siswa di SMA Negeri 1 Kota Sungai Penuh".

Penelitian ini bertujuan untuk memperoleh gambaran yang jelas dari yang diteliti, dalam hal ini yang menjadi tujuan penelitian adalah untuk mengetahui upaya guru Pendidikan Agama Islam dalam meningkatkan kemampuan membaca Alquran siswa di SMA Negeri 1 Kota Sungai Penuh dan mengetahui faktor pendukung dan penghambat upaya guru Pendidikan Agama Islam dalam meningkatkan kemampuan membaca Alquran siswa di SMA Negeri 1 Kota Sungai Penuh. Maka dari itu, Tulisan ini akan mendeskripsikan lebih lanjut terkait upaya guru pendidikan agama islam dan juga faktor pendukung dan penghambat upaya guru pendidikan agama islam dalam meningkatkan kemampuan membaca Alquran siswa di SMA Negeri 1 Kota Sungai Penuh.

\section{Tinjauan Pustaka}

\section{Guru}

Guru adalah seorang pendidik yang memberi pengaruh besar kepada pengetahuan serta karakter siswa. Guru yang memberikan contoh baik dari segi karakter maupun ilmu 
pengetahuan terhadap siswa sangat mempengaruhi siswa baik di lingkungan sekolah maupun di lingkungan masyarakat (Karso, 2019: 383).

Seorang guru harus memiliki 4 kompetensi salah satunya yaitu pedagogik yang mengharuskan guru mempunyai pengetahuan dan ketrampilan yang berkaitan dengan proses pembelajaran, khususnya guru Pendidikan Agama Islam harus mempunyai ketrampilan dalam proses pembelajaran baca tulis Alquran dikarenakan siswa selain harus berprestasi dalam pengetahuan umum siswa harus juga memiliki kemampuan membaca Alquran sesuai dengan ilmu tajwid yang baik dan benar.

2. Pendidikan Agama Islam

Menurut Majid dalam Sari (2018:10) Pendidikan Agama Islam adalah upaya sadar dan terencana dalam mempersiapkan siswanya untuk mengenal, memahami, menghayati, hingga mengimani, bertakwa, dan berakhlak mulia dalam mengamalkan ajaran Agama Islam dari sumber utamanya Alquran dan Al-Hadits, melalui kegiatan kegiatan bimbingan, pengajaran, latihan, serta penggunaan pengalaman.

Berdasarkan pengertian diatas dapat diambil kesimpulan bahwa yang dimaksud guru Pendidikan Agama Islam adalah seorang yang memiliki profesi sebagai guru yang dengan sadar mendidik, membimbing dan bertanggungjawab terhadap anak-anak didiknya kearah pencapaian kedewasaan serta terbentuknya perilaku anak yang Islami sehingga terjalin keseimbangan, kebahagiaan dunia dan akhirat.

Tujuan pendidikan agama Islam haruslah mencakup ketiga hal tersebut yaitu agar peserta didik menjadi manusia yang mampu menggunakan ilmu pengetahuan dan keterampilan untuk selalu kembali kepada Tuhan, dan menjadi manusia yang mampu memanfaatkan ilmu pengetahuan dan keterampilannya untuk mencapai kebahagiaan di dunia maupun di akhirat, dan dengan keluasan ilmu pengetahuannya tersebut dapat menjadikannya sebagai manusia yang taat dan shalih, sehingga apabila kesemuanya dimiliki peserta didik, titik akhirnya adalah mewujudkan peserta didik menjadi insan kamil (Frimayanti, 2017:240).

\section{Alquran}

Alquran merupakan pedoman pertama dan utama bagi umat islam. Alquran diturunkan dalam bahasa arab, kepada nabi Muhammad SAW melalui malaikat jibril. Alquran sebagai lentera kehidupan bukan hanya pada tau dan paham tentang isi dari kandungannya namun juga pada pengetahuan dan pemahaman cara mengkaji Alquran (Jull, 2021: 1).

Kemampuan berasal dari kata "mampu" yang mendapat awalan "ke" dan akhiran "an", sehingga menjadi kata benda abstrak "kemampuan" yang mempunyai arti kesanggupan atau kecakapan. Yang dimaksud kemampuan dalam tulisan ini adalah kesanggupan atau kecakapan yang berkaitan dengan keterampilan membaca Alquran dengan baik dan benar (Khasanah, 2019:14).

Metode Belajar Membaca Alquran di antaranya:

Pertama, Metode Iqra' yaitu suatu metode membaca Al-Qur"an yang menekankan kepada latihan membaca. Adapun panduan Iqro" terdiri dari 6 jilid dimulai tingkat yang paling sederhana, tahap demi tahap sampan dengan tingkatan yang sempurna (Kustianingrum, 2020:3). Kedua, Metode qira'ati menurut Sophya \& Mujab dalam Sari (2018:25) Metode Qira'ati yaitu sama metode membaca Alquran yang langsung memasukan kaidah-kaidah tajwid didalam bacaan-bacaan secara praktis tanpa harus mempelajari ilmu tajwidnya, sehingga dapat langsung membaca tartil. Ketiga, Metode tartil menurut Sophya \& Mujab dalam Sari (2018:25) Metode Qira'ati yaitu sama metode membaca Alquran yang langsung memasukan kaidah-kaidah tajwid didalam bacaan-bacaan secara praktis tanpa harus mempelajari ilmu tajwidnya, sehingga dapat langsung membaca tartil. Keempat, Metode Sima'I menurut Ahsin W. Al-Hafidz dalam Sari (2018:28) adalah mendengar, yang dimaksud metode ini adalah mendengarkan suatu bacaan untuk dihafalkan. Metode ini sangat efektif bagi penghafal yang mempunyai daya ingat ekstra. Metode ini dapat dilakukan oleh gurunya, karena dalam hal ini guru berperan aktif untuk membacakan satu persatu ayat yang harus dihafalkan, kemudian diputar dan didengar sambil mengikutinya secara perlahan. Kelima, 
Metode Tilawati menurut Ihrom dalam Rasyid \& Asy-Syahida (2020:188) Metode tilawati dalam pembelajaran Alquran menurut Misbahul Munir yang dikutip yaitu suatu metode atau cara belajar membaca Alquran dengan ciri khas menggunakan lagu rost dan menggunakan pendekatan yang seimbang antara pembiasaan melalui klasikal dan kebenaran membaca melalui individual dengan teknik baca simak.

Menurut Hakim, R. (2014: 126), Keistimewaan tilawah adalah bahwa Alquran adalah sebuah kitab yang harus dibaca, bahkan dianjurkan untuk dijadikan bacaan harian. Membacanya dinilai oleh Allah SWT sebagai ibadah. Pahala yang diberikan pembacanya berlipat ganda, sebagaimana sabda Rasulullah SAW "Saya tidak mengatakan alif lam mim itu satu huruf, namun alif satu huruf, lam satu huruf, dan mim satu huruf." (H.R. al-Tirmidzi). Pada hakikatnya tilawah bukanlah hal yang sederhana, namun dalam bertilawah seorang qari' (pembaca) dituntut untuk menjaga keaslian bacaan Al-Quran seperti yang diturunkan Allah kepada Nabi Muhammad SAW melalui Jibril. Firman Allah: Apabila Kami telah membacanya maka ikutilah bacaannya itu (Q.S. al-Qiyamah 75:18).

\section{Metode}

Dalam penelitian ini, jenis penelitian yang digunakan adalah penelitian kualitatif dengan pendekatan studi lapangan. Darmalaksana (2020:5) menjelaskan bahwa "Data hasil studi lapangan ditampilkan sebagai temuan penelitian, diabstraksikan untuk mendapatkan informasi yang utuh, dan dinterpretasi hingga menghasilkan pengetahuan untuk penarikan kesimpulan." Informan dalam penelitian ini ditetapkan berdasarkan teknik purposive sampling. Peneliti menetapkan beberapa orang informan yakni: 1) kepala sekolah; 2) wakil kepala sekolah bidang kesiswaan; 3) guru Pendidikan Agama Islam; 4) beberapa perwakilan siswa kelas 11 dan kelas 12 di SMA Negeri 1 Kota Sungai Penuh. Teknik analisis data dalam penelitian ini menggunakan 3 tahap yakni reduksi data, analisis data dan penyimpulan data.

\section{Hasil dan Pembahasan}

Bersumber dari informasi yang diperoleh melalui observasi dan wawancara bersama guru pendidikan agama islam juga beberapa siswa di lapangan, penulis menemukan upaya guru Pendidikan Agama Islam dalam meningkatkan kemampuan membaca Alquran siswa di SMA Negeri 1 Kota Sungai Penuh sebagai berikut:

1. Upaya Guru Pendidikan Agama Islam dalam Meningkatkan Kemampuan Membaca Alquran Siswa di SMA Negeri 1 Kota Sungai Penuh

Data yang diperoleh berkaitan dengan data sekolah dan tentang Upaya guru Pendidikan Agama Islam dalam meningkatkan kemampuan membaca Alquran siswa di SMA Negeri 1 Kota Sungai penuh berikut adalah nama-nama informan:

Tabel 1. Nama Informan (Waka Kurikulum, Guru, Staff TU)

\begin{tabular}{|c|l|l|}
\hline No. & \multicolumn{1}{|c|}{ Nama } & \multicolumn{1}{c|}{ Jabatan } \\
\hline 1. & Armen Marta, S.Si. & $\begin{array}{l}\text { Wakil kepala sekolah } \\
\text { bidang kurikulum }\end{array}$ \\
\hline 2. & Mikson, S.Kom. & Staff TU \\
\hline 3. & Hermina, S.Ag. & Guru PAI \\
\hline 4. & Eny Sepriyanti, S.PdI. & Guru PAI \\
\hline 5. & Ririn Nopiardi, S.Pd. & Guru PAI \\
\hline 6. & Herlina, S.PdI. & Guru PAI \\
\hline
\end{tabular}


Tabel 2. Nama Informan ( Siswa Kelas XI)

\begin{tabular}{|c|l|l|}
\hline No. & \multicolumn{1}{|c|}{ Nama } & \multicolumn{1}{|c|}{ Kelas } \\
\hline 1. & Yola Ukhtiani & XI IPS 1 \\
\hline 2. & Naffa Asti Aprilia & XI IPS 1 \\
\hline 3. & Muhammad Naufal Azmi & XI IPS 1 \\
\hline 4. & Urmila Sabrina Aazhara & XI IPS 1 \\
\hline 5. & Maya Tanjung & XI IPS 1 \\
\hline 6. & Meka Sutri Utami & XI IPS 1 \\
\hline 7. & Muhammad Fadil & XI IPS 1 \\
\hline $\mathbf{8 .}$ & Nasrul Taufik Hidayah & XI IPS 1 \\
\hline 9. & Olyvia Zafira & XI IPS 1 \\
\hline 10. & Muhammad Rayhan & XI IPS 1 \\
\hline 11. & Selvia Rahmadani & XI IPS 1 \\
\hline 12. & Zaki Alhazbi & XI IPS 1 \\
\hline 13. & Rafika Aulia & XI IPS 1 \\
\hline
\end{tabular}

Tabel 3. Nama Informan (Siswa Kelas XII)

\begin{tabular}{|c|c|c|}
\hline No. & Nama & Kelas \\
\hline 14. & Resya Rahmani & XII MIPA 3 \\
\hline 15. & Fauzan Simamora & XII MIPA 3 \\
\hline 16. & Muhammad Fajar & XII MIPA 3 \\
\hline 17. & Aditya Bhayangkara & XII MIPA 3 \\
\hline 18. & Nia Ardani & XII MIPA 3 \\
\hline 19. & Dara Puti Anisa & XII MIPA 3 \\
\hline 20. & Questa Soundri & XII MIPA 3 \\
\hline 21. & Riski Salsabila & XII MIPA 3 \\
\hline 22. & Diva Permata Dini & XII MIPA 3 \\
\hline 23. & Fanisa Izati & XII MIPA 3 \\
\hline 24. & Desta Nevia & XII MIPA 3 \\
\hline 25. & Felisha Aliyah & XII MIPA 3 \\
\hline 26. & Jovita Melany & XII MIPA 3 \\
\hline
\end{tabular}

Setelah dilakukan wawancara dan observasi di lapanga, peneliti menemukan data tentang upaya guru PAI dalam meningkatkan kemampuan membaca Alquran siswa di SMA Negeri 1 Kota Sungai Penuh sebagai berikut:

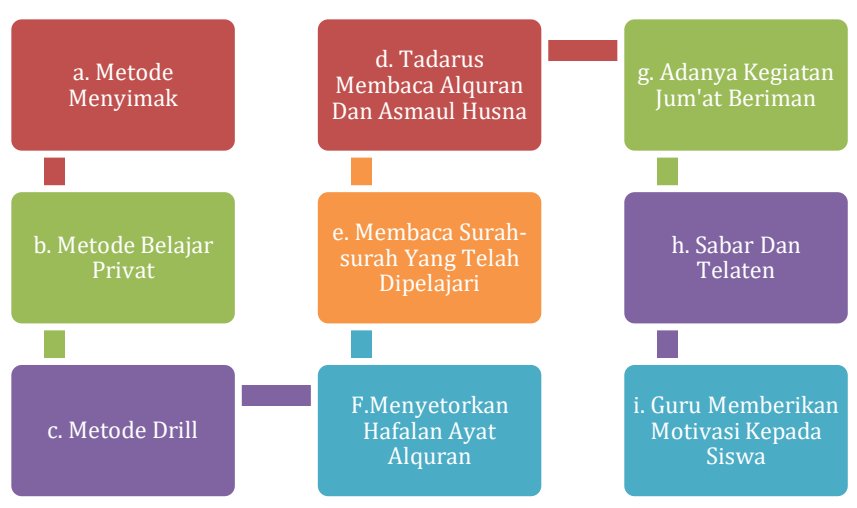

Gambar 1. Upaya Guru PAI dalam Meningkatkan Kemampuan Membaca Alquran Siswa 
Salma Jihan Utami dan Ahmad Kosasih: Upaya Guru Pendidikan Agama Islam dalam Meningkatkan...

Berdasarkan gambar 1, dapat penulis jelaskan bahwa setelah diadakan wawancara mendalam dengan informan maka terdapat delapan upaya guru PAI dalam meningkatkan kemampuan membaca Alquran siswa, sembilan tema tersebut adalah i) metode menyimak ii) metode belajar privat (face to face), iii) metode drill, iv) Tadarus Alquran dan membaca asmaul husna, v) membaca surah-surah yang telah dipelajari, vi) menyetorkan hafalan ayat Alquran, vii) adanya kegiatan jum'at beriman, viii) sabar dan telaten, ix) guru memberikan motvasi kepada siswa.

Berikut ini akan penulis deskripsikan kutipan hasil wawancara dengan informan berdasarkan sembilan tema sebagaimana telah dijelaskan di atas. Adapun deskripsi wawancara yang akan penulis tampilkan adalah kutipan pernyataan singkat dari informan ketika wawancara dilakukan. Kutipan-kutipan wawancara tersebut walaupun disampaikan informan dalam redaksi bahasa yang sedikit berbeda-beda, namun sebenarnya mempunyai tujuan dan maksud yang kurang lebih sama.

Tema pertama yaitu, menurut informan salah satu upaya guru PAI dalam meningkatkan kemamuan membaca Alquran siswa adalah dilakukannya metode menyimak, Tema ini dinyatakan oleh informan sebagaimana petikan wawancara pada tabel 4 berikut:

Tabel 4. Petikan Wawancara Tema Pertama

\begin{tabular}{|c|c|c|}
\hline Tema & Informan & Petikan Wawancara \\
\hline \multirow[t]{4}{*}{$\begin{array}{l}\text { Metode } \\
\text { menyimak }\end{array}$} & Siswa & $\begin{array}{l}\text { Iya guru meminta untuk menyimak dengan baik bacaan yang } \\
\text { benar yang telah di contohkan oleh guru agama di depan kelas } \\
\text { dengan baik. }\end{array}$ \\
\hline & Siswa & $\begin{array}{l}\text { Melakukan penerapan metode menyimak kepada siswa yang } \\
\text { dilakukan di kelas... }\end{array}$ \\
\hline & Siswa & $\begin{array}{l}\text { Biasanya itu di kelas guru agama menjelaskan didepan kelas, } \\
\text { diterangkan di papan tulis setelah itu siswanya juga dites satu } \\
\text { persatu atau bisa juga dengan didengarkan siswa membaca } \\
\text { Alquran kalau kekeliruan atau kesalahan siswa tersebut } \\
\text { diperbaiki dan dikoreksi. }\end{array}$ \\
\hline & Siswa & $\begin{array}{l}\text {... Guru meminta kepada siswa untuk menyimak dengan baik } \\
\text { lalu mengoreksi apakah siswa tersebut ada yang sudah atau } \\
\text { belum dalam membaca Alquran." }\end{array}$ \\
\hline
\end{tabular}

Tema kedua yaitu metode belajar privat (face to face), menurut informan metode face to face ini adalah metode yang sering diterapkan oleh guru pendidikan agama islam di kelas. Tema ini dinyatakan oleh informan dari beberapa siswa sebagaimana petikan wawancara pada tabel 5 berikut:

\section{Tabel 5. Petikan Wawancara Tema Kedua}

\begin{tabular}{|c|c|c|}
\hline Tema & Informan & Petikan Wawancara \\
\hline \multirow{4}{*}{$\begin{array}{l}\text { Metode } \\
\text { belajar } \\
\text { privat } \\
\text { (face to } \\
\text { face) }\end{array}$} & Siswa & $\begin{array}{l}\text { Sistem sorogan atau individu (privat). Dalam prakteknya } \\
\text { siswa bergiliran satu pertemuan menurut terjemahan } \\
\text { bacaannya, (mungkin satu, dua atau tiga bahkan halaman). }\end{array}$ \\
\hline & Siswa & $\begin{array}{l}\text { Sistem individu yaitu para siswa satu persatu mempratekan } \\
\text { kemampuan membaca Alquran, Membaca dengan serentak } \\
\text { bersama siswa lain. Mengawali kegiatan belajar mengajar } \\
\text { dengan membaca alquran di setiap pagi. }\end{array}$ \\
\hline & Siswa & $\begin{array}{l}\text { Dengan cara melakukan tes untuk penilaian praktek guru } \\
\text { biasanya akan menguji siswa membaca Alquran... }\end{array}$ \\
\hline & Siswa & $\begin{array}{l}\text {...Dengan cara melakukan penilaian kepada siswa satu per } \\
\text { satu. karena penilaian tersebut akan digunakan agar lebih } \\
\text { memantapkan bacaan Alquran siswa tersebut. }\end{array}$ \\
\hline
\end{tabular}




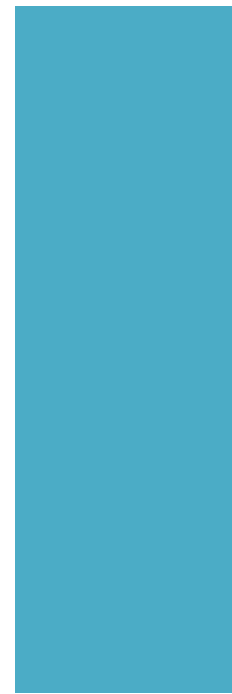

\begin{tabular}{c|l} 
Siswa & $\begin{array}{l}\text { Dengan menggunakan Sistem individu yaitu para siswa satu } \\
\text { persatu mempratekan kemampuan membaca Al-Quran, } \\
\text { Membaca dengan serentak bersama siswa lain. }\end{array}$ \\
Siswa & $\begin{array}{l}\text { Biasanya dalam meningkatkan kemampuan membaca Alquran } \\
\text { siswa guru agama melakukan tes dan menguji bagaimana } \\
\text { siswa membaca Alquran... }\end{array}$ \\
Siswa & $\begin{array}{l}\text { Guru Agama menggunakan Sistem individu yaitu para siswa } \\
\text { satu persatu mempratekan kemampuan membaca Al-Quran } \\
\text { dengan face to face. }\end{array}$ \\
Siswa & $\begin{array}{l}\text { Biasanya di kelas guru menggunakan sistem individu gitu kak } \\
\text { yang mana para siswa-siswi satu persatu mempratekan } \\
\text { kemampuan membaca Alquran maju satu persatu di depan } \\
\text { kelas." } \\
\text {,... penerapan metode belajar privat (face to face), tadarus } \\
\text { Alquran setiap hari. }\end{array}$ \\
Siswa
\end{tabular}

Tema ketiga yaitu metode drill, Dalam metode drill digunakan guru pendidikan agama islam dikelas. Tema ini dinyatakan oleh informan sebagaimana petikan wawancara pada tabel 6 berikut:

Tabel 6. Petikan Wawancara Tema Ketiga

\begin{tabular}{l|l|l}
\multicolumn{1}{c|}{ Tema } & Informan & \multicolumn{1}{c}{ Petikan Wawancara } \\
Metode & Siswa & $\begin{array}{l}\text { Dimana guru agama menggunakan suatu cara yang dapat } \\
\text { drill }\end{array}$ \\
& $\begin{array}{l}\text { datihan-latihan agar menan suatu cara mengajar dimana melaksanakan } \\
\text { keterampilan lebih dari apa yang telah dipelajari di kelas } \\
\text { seperti lancar dalam membaca Alquran sesuai dengan ilmu } \\
\text { tajwid. }\end{array}$
\end{tabular}

Tema keempat yaitu Kegiatan yang dilakukan setiap hari sebelum memulai kegiatan pembelajaran dikelas. Tema ini dinyatakan oleh informan yaitu guru PAI dan siswa sebagaimana petikan wawancara pada tabel 7 berikut:

\section{Tabel 7. Petikan Wawancara Tema Keempat}

\begin{tabular}{|c|c|c|}
\hline Tema & Informan & Petikan Wawancara \\
\hline \multirow{6}{*}{$\begin{array}{l}\text { Tadarus } \\
\text { Alquran } \\
\text { Dan } \\
\text { Membaca } \\
\text { Asmaul } \\
\text { Husna }\end{array}$} & Guru PAI & $\begin{array}{l}\text { Membaca ayat itu minimal } 3 \text { kali ualng ibuk seperti itu teorinya. } \\
\text { Dan juga di sekolah itu ada kebiasaan membaca asmaul husna } \\
\text { sebelum pbm di kelas dimulai. }\end{array}$ \\
\hline & Siswa & $\begin{array}{l}\text { Setiap memulai pembelajaran agama guru pendidikan agama } \\
\text { islam meminta siswa siswi dikelas untuk tadarus Alquran,... }\end{array}$ \\
\hline & Siswa & $\begin{array}{l}\text { Makin lancar membaca Alqurannya dan tau tentang ilmu } \\
\text { tajwidnya. Biasanya dengan cara disuruh maju satu persatu } \\
\text { membaca Alquran kadang-kadang juga diminta membaca secara } \\
\text { bersama-sama. }\end{array}$ \\
\hline & Siswa & $\begin{array}{l}\text { Dengan cara guru meminta siswa membaca Alquran bersama- } \\
\text { sama disaat pelajaran agama. }\end{array}$ \\
\hline & Siswa & $\begin{array}{l}\text { Biasanya guru agama melakukan metode tadarus sebelum } \\
\text { belajar. contohnya QS. Ali Imran ayat } 190 \text { beserta artinya. }\end{array}$ \\
\hline & Siswa & $\begin{array}{l}\text { Guru meluangkan waktu sedikit waktu sebelum pelajaran di } \\
\text { mulai untuk membaca dan melatih kemampuan siswa dalam } \\
\text { membaca Alquran, sedikit-sedikitnya } 15 \text { menit sebelum PBM } \\
\text { dimulai. }\end{array}$ \\
\hline
\end{tabular}


Salma Jihan Utami dan Ahmad Kosasih: Upaya Guru Pendidikan Agama Islam dalam Meningkatkan...

Tema kelima Kegiatan mengulangi mempelajari surah-surah dalam Alquran. Tema ini dinyatakan oleh informan yaitu siswa sebagaimana petikan wawancara pada tabel 8 berikut:

\section{Tabel 8. Petikan Wawancara Tema Kelima}

\begin{tabular}{|c|c|c|}
\hline Tema & Informan & Petikan Wawancara \\
\hline \multirow{5}{*}{$\begin{array}{l}\text { Membaca } \\
\text { surah- } \\
\text { surah } \\
\text { yang } \\
\text { telah } \\
\text { dipelajari, } \\
\text { membaca } \\
\text { surah- } \\
\text { surah } \\
\text { pendek } \\
\text { dalam } \\
\text { Alquran }\end{array}$} & Siswa & $\begin{array}{l}\text { Guru biasanya meminta siswa untuk membaca surah-surah } \\
\text { pendek di dalam Alquran maupun yang ada di dalam LKS } \\
\text { ataupun buku paket mata pelajaran agama sebelum memulai } \\
\text { pembelajaran }\end{array}$ \\
\hline & Siswa & $\begin{array}{l}\text { Guru biasanya akan menyuruh kita mengasah bacaan Alquran } \\
\text { dengan membaca ayat ayat yang sering kita temui di dalam } \\
\text { buku pelajaran. Ada biasanya guru akan mengadakan ujian } \\
\text { lisan seperti hapalan surah surah pendek yang ada di dalam } \\
\text { Alquran. }\end{array}$ \\
\hline & Siswa & $\begin{array}{l}\text { Biasanya dalam kelas itu terdapat sebelum belajar itu } \\
\text { membaca do'a sesuai dengan kepercayaan masing-masing dan } \\
\text { membaca surah surah pendek. }\end{array}$ \\
\hline & Siswa & $\begin{array}{l}\text { Guru biasanya meminta siswa untuk membaca surah-surah } \\
\text { pendek di dalam Alquran maupun yang ada di dalam LKS } \\
\text { ataupun buku paket mata pelajaran agama sebelum memulai } \\
\text { pembelajaran }\end{array}$ \\
\hline & Siswa & $\begin{array}{l}\text { Biasanya dalam kelas itu terdapat sebelum belajar itu } \\
\text { membaca do'a sesuai dengan kepercayaan masing-masing dan } \\
\text { membaca surah surah pendek }\end{array}$ \\
\hline
\end{tabular}

Tema keenam yaitu Guru agama juga mengadakan kegiatan setor hafalan ayat Alquran kepada siswa, tema ini disampaikan informan sebagaimana terlihat pada petikan wawancara pada tabel 9 berikut:

Tabel 9. Petikan Wawancara Tema Keenam

\begin{tabular}{|c|c|c|}
\hline Tema & Informan & Petikan Wawancara \\
\hline \multirow[t]{2}{*}{$\begin{array}{l}\text { Menyeto } \\
\text { rkan } \\
\text { fafalan } \\
\text { Alquran }\end{array}$} & Siswa & $\begin{array}{l}\text { Ada yaitu kegiatan khususnya tugas rumah seperti siswa } \\
\text { diberikan latihan dan menghafal surah yang biasa dibaca sesuai } \\
\text { dengan yang pernah dipelajari sebelumnya seperti ayat } \\
\text { mengenai cara berpakaian muslim dan muslimah dengan baik } \\
\text { di dalam agama islam }\end{array}$ \\
\hline & Siswa & $\begin{array}{l}\text { Dengan Selalu Menghafalkan Alquran dan Selalu Menyetor } \\
\text { Hafalan Sesuai Kemampuan Pribadi. }\end{array}$ \\
\hline
\end{tabular}

Tema ketujuh yaitu Adanya suatu kegiatan di sekolah yaitu kegiatan jum'at beriman., tema ini disampaikan informan sebagaimana terlihat pada petikan wawancara pada tabel 10 berikut:

\section{$\mathbf{T}$}

Tabel 10. Petikan Wawancara Tema Ketujuh

\begin{tabular}{|c|c|c|}
\hline Tema & Informan & Petikan Wawancara \\
\hline \multirow[t]{2}{*}{$\begin{array}{l}\text { Kegiatan } \\
\text { Jum'at } \\
\text { Beriman }\end{array}$} & Guru PAI & $\begin{array}{l}\text { Ada rohis ya kalau rohis disini setiap pagi jum'at biasanya } \\
\text { membaca yasin jadi pas kita mau baca yasin itu anak-anakjuga } \\
\text { bisa baca yasin nanti juga bisa diartikan membaca Alquran } \\
\text { bukan jadi mereka bisa in syaa Allah sudah bisa membaca } \\
\text { Alquran dengan lancar setiap jum'at itu ada namanya kegiatan } \\
\text { jum'at beriman namanya }\end{array}$ \\
\hline & Siswa & $\begin{array}{l}\text { Pada setiap hari jum'at biasanya siswa bersama-sama membaca } \\
\text { yasin dan selanjutnya membaca asmaul husna di lapangan }\end{array}$ \\
\hline
\end{tabular}


Siswa Mengawali kegiatan belajar mengajar dengan membaca Alquran di setiap pagi dan mengadakan kegiatan rohis setiap jumat pagi.

Tema kedelapan yaitu sabar dan telaten guru sebagai seorang pendidik diharuskan memiliki sifat sabar serta telaten dalam memberi ilmu kepada siswa-siswinya tema ini disampaikan informan sebagaimana terlihat pada petikan wawancara pada tabel 11 berikut:

Tabel 11. Petikan Wawancara Tema Kedelapan

\begin{tabular}{|c|c|c|}
\hline Tema & Informan & Petikan Wawancara \\
\hline \multirow[t]{2}{*}{$\begin{array}{l}\text { Sabar } \\
\text { dan } \\
\text { telaten }\end{array}$} & Siswa & $\begin{array}{l}\text { Sabar dan telaten guru agama dalam mengajarkan membaca } \\
\text { Alquran membuahkan hasil dimana siswa dari yang masih } \\
\text { terbata-bata dalam membaca menjadi lancar dalam membaca } \\
\text { Alquran sesuai ilmu tajwid }\end{array}$ \\
\hline & Siswa & $\begin{array}{l}\text { Dalam membagikan ilmu yang guru agama miliki seperti ilmu } \\
\text { tajwid. Didalam kelas guru sangat sabar dan teliti agar siswa } \\
\text { siswi dapat mengerti dan memahami dengan baik, walaupun } \\
\text { masih ada teman-teman lain yang tidak memperhatikannya }\end{array}$ \\
\hline
\end{tabular}

Tema kesembilan yaitu guru sebagai motivator bagi siswa-siswinya memang seharusnya memberikan nasihat-nasihat maupun kata-kata penyemangat untuk siswanya dalam hal belajar salah satu dalam membaca Alquran. Agar siswa terdorong untuk terus belajar maupun memperbaiki bacaan Alquran agar sesuai dengan ilmu tajwid yang baik dan benar. tema ini disampaikan informan sebagaimana terlihat pada petikan wawancara pada tabel 12 berikut:

Tabel 12. Petikan Wawancara Tema Kesembilan

\begin{tabular}{|c|c|c|}
\hline Tema & $\begin{array}{l}\text { Inform } \\
\text { an }\end{array}$ & Petikan Wawancara \\
\hline \multirow{3}{*}{$\begin{array}{l}\text { Guru } \\
\text { member } \\
\text { ikan } \\
\text { motivasi } \\
\text { kepada } \\
\text { siswa }\end{array}$} & Siswa & $\begin{array}{l}\text { Dengan cara pada saat penilaian membaca Alquran dari bacaan } \\
\text { para siswa guru agama juga mengajarkan hukum tajwid kepada } \\
\text { para siswa dan memberi motivasi tentang kewajiban membaca } \\
\text { Alquran selalu akan menjadi penyemangat siswa. }\end{array}$ \\
\hline & Siswa & $\begin{array}{l}\text { Memberi motivasi kepada siswa dengan cara memberikan nasihat- } \\
\text { nasihat, menumbuhkan minat siswa, dan menerapkan metode } \\
\text { efektif yang digunakan guru dalam meningkatkan kemampuan } \\
\text { membaca Alquran. Ada seperti menyetor hafalan setiap bulannya } \\
\text { atau minggu. }\end{array}$ \\
\hline & Siswa & $\begin{array}{l}\text { Iya karena upaya yang dilakukan oleh guru agama tersebut } \\
\text { mempengaruh dan banyak mendapat dukungan dan juga } \\
\text { meningkat dengan adanya motivasi yang guru berikan kepada } \\
\text { siswa }\end{array}$ \\
\hline
\end{tabular}

Faktor pendukung:

1. Adanya internet
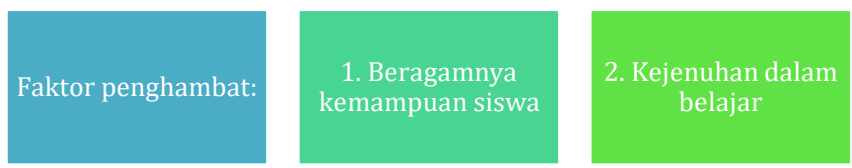

2. Semangat dan motivasi siswa

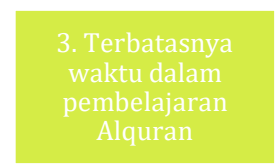

Gambar 2. Faktor Pendukung dan Penghambat 
Salma Jihan Utami dan Ahmad Kosasih: Upaya Guru Pendidikan Agama Islam dalam Meningkatkan...

Berdasarkan gambar 2, dapat penulis jelaskan bahwa setelah diadakan wawancara mendalam dengan informan maka terdapat dua faktor pendukung dan 4 faktor penghambat upaya guru PAI dalam meningkatkan kemampuan membaca Alquran siswa, dua tema faktor pendukung tersebut adalah i) adanya internet ii) semangat dan motivasi siswa, dan 4 tema faktor penghambat tersebut adalah i) beragamnya kemampuan siswa, ii) kejenuhan dalam belajar, iii) terbatasnya waktu dalam pembelajaran Alquran, iv) kurangnya perhatian dari orang tua dalam hal membaca Alquran.

Berikut ini akan penulis deskripsikan kutipan hasil wawancara dengan informan berdasarkan sembilan tema sebagaimana telah dijelaskan di atas. Adapun deskripsi wawancara yang akan penulis tampilkan adalah kutipan pernyataan singkat dari informan ketika wawancara dilakukan. Kutipan-kutipan wawancara tersebut walaupun disampaikan informan dalam redaksi bahasa yang sedikit berbeda-beda, namun sebenarnya mempunyai tujuan dan maksud yang kurang lebih sama.

a. Faktor Pendukung

Tema pertama yaitu Dengan adanya internet mempermudah guru agama islam dalam melakukan upaya dalam meningkatkan kemampuan membaca Alquran siswa. Tema ini dinyatakan oleh informan sebagaimana petikan wawancara pada tabel 13 berikut:

Tabel 13. Petikan Wawancara Tema Pertama

\begin{tabular}{ll|l}
\multicolumn{1}{c}{ Tema } & Informan & \multicolumn{1}{c}{ Petikan Wawancara } \\
Adanya & Guru PAI & $\begin{array}{l}\text { Mendengar bacaan yang betul bacaan yang benar itu seperti } \\
\text { apa setelah itu di tes lagi bisa tidak anak anak tersebut } \\
\text { menirukan bacaan yang benar yang telah di dengar melalui } \\
\text { seperti murottal tadi. Mendengar ini bisa gurunya langsung } \\
\text { yang bacakan bisa juga anak-anak ambil di internet tentang } \\
\text { bagaimana membaca Alquran dengan benar itu. }\end{array}$
\end{tabular}

Tema kedua yaitu Dengan adanya semangat serta motivasi siswa tercapainya peningkatan secara terus menerus kepada siswa khusunya dalam hal membaca Alquran. Tema ini dinyatakan oleh informan sebagaimana petikan wawancara pada tabel 14 berikut:

Tabel 14. Petikan Wawancara Tema Kedua

\begin{tabular}{|c|c|c|}
\hline Tema & Informan & Petikan Wawancara \\
\hline $\begin{array}{l}\text { Semangat } \\
\text { dan } \\
\text { motivasi } \\
\text { siswa }\end{array}$ & Guru PAI & $\begin{array}{l}\text { Kebanyakan siswa minta belajar dari rumah gitu kebanyakan. } \\
\text { Motivasi siswa itu harus di bangkitkan, rugi kalau tidak bisa } \\
\text { membaca Alquran. Kasih motivasi dulu gambarannya rugi } \\
\text { kalau kita tidak bisa membaca Alquran. Kalau Alquran yang ada } \\
\text { terjemahan juga memudah siswa dalam membaca Alquran } \\
\text { sekaligus dengan terjemahan dari ayat Alquran tersebut }\end{array}$ \\
\hline
\end{tabular}

b. Faktor Penghambat

Tema pertama yaitu Kemampuan setiap siswa pasti beragam, ada siswa yang cepat mengerti dan ada juga tidak. Tema ini dinyatakan oleh informan sebagaimana petikan wawancara pada tabel 15 berikut:

Tabel 15. Petikan Wawancara Tema Pertama

\begin{tabular}{l|ll}
\multicolumn{1}{c}{ Tema } & Informan & \multicolumn{2}{c}{ Petikan Wawancara } \\
Keberagamannya & Guru PAI & $\begin{array}{l}\text { Hambatannya itu tergantung dari anaknya gitu kalau } \\
\text { kemampuan }\end{array}$ \\
siswa & $\begin{array}{l}\text { membaca Alquran supaya dia bisa mendatangi gurunya } \\
\text { untuk belajar Alquran }\end{array}$
\end{tabular}

Tema kedua yaitu kejenuhan dalam belajar dalam proses pembelajaran pasti terdapat kejenuhan belajar yang dirasakan oleh siswa. Tema ini dinyatakan oleh informan sebagaimana petikan wawancara pada tabel 16 berikut: 
Tabel 16. Petikan Wawancara Tema Kedua

\begin{tabular}{|c|c|c|}
\hline Tema & Informan & Petikan Wawancara \\
\hline $\begin{array}{l}\text { Kejenuhan } \\
\text { dalam } \\
\text { belajar }\end{array}$ & Guru PAI & $\begin{array}{l}\text { Pasti ya kalau di dalam kelas itu beberapa siswa tidak } \\
\text { memperhatikan disaat guru agama menjelaskan pelajaran di } \\
\text { depan kelas, adanya rasa bosan dalam pembelajaran makanya } \\
\text { tidak fokus disaat guru agama menerangkan pelajaran di } \\
\text { kelas, disaat guru agama menanyakan soal pelajaran bagi } \\
\text { siswa yang tidak memperhatikan tadi itu pasti siswa tersebut } \\
\text { cemas akan jawaban yang akan dijawabnya karena memang } \\
\text { tidak ada memperhatikan. Jadi kejenuhan maupun rasa bosan } \\
\text { siswa dalam belajar itu tidak selalu soal guru agama tidak } \\
\text { memiliki metode yang menarik kadang ada beberapa siswa } \\
\text { yang memang tidak memiliki motivasi maupun usahanya } \\
\text { dalam belajar. Itu salah satu hambatan yang ada di dalam } \\
\text { kelas saatpbm berlangsung ya }\end{array}$ \\
\hline
\end{tabular}

Tema ketiga yaitu Dalam waktu pembelajaran pendidikan agama islam memiliki keterbatasan dalam hal pembelajaran Alquran dikarenakan sedikitnya waktu. Tema ini dinyatakan oleh informan sebagaimana petikan wawancara pada tabel 17 berikut:

\section{Tabel 17. Petikan Wawancara Tema Ketiga}

\begin{tabular}{|c|c|c|}
\hline Tema & Informan & Petikan Wawancara \\
\hline $\begin{array}{l}\text { Keterbatasan } \\
\text { waktu dalam } \\
\text { belajar } \\
\text { Alquran }\end{array}$ & Guru PAI & $\begin{array}{l}\text { Jadi terbatasnya waktu dalam mempelajari Alquran itu } \\
\text { dikarena ya dalam } 1 \text { pekan itu di SMA Negeri } 1 \text { Kota Sungai } \\
\text { Penuh hanya belajar pelajaran agama hanya } 3 \text { jam } \\
\text { pelajaran } 1 \text { jam itu } 45 \text { menit. Jadi memang untuk } \\
\text { memfokuskan siswa dalam } 1 \text { pekan itu khusus belajar } \\
\text { membaca Alquran dengan baik sesuai dengan ilmu tajwid itu } \\
\text { terbilang susah karena banyak materi-materi yang sesuai } \\
\text { dengan silabus nanti itu tidak dapat dijelaskan sesuai } \\
\text { memang jadwalnya membahas materi itu pada pertemuan } \\
\text { itu. Jadi memang sebelum PBM dimulai ada } 15 \text { Menit tiap } \\
\text { harinya untuk mempelajari Alquran itu ya dengan } \\
\text { melakukan tadarus secara bersama-sama termasuk mata } \\
\text { pelajaran lain. Tapi ada juga beberapa siswa yang menemui } \\
\text { guru agama secara langsung diluar jam pelajaran karena } \\
\text { terbatasnya waktu belajaragama di kelas. }\end{array}$ \\
\hline
\end{tabular}

Tema keempat yaitu Dalam waktu pembelajaran pendidikan agama islam memiliki keterbatasan dalam hal pembelajaran Alquran dikarenakan sedikitnya waktu. Tema ini dinyatakan oleh informan sebagaimana petikan wawancara pada tabel 18 berikut:

Tabel 18. Petikan Wawancara Tema Keempat

\begin{tabular}{|c|c|c|}
\hline Tema & Informan & Petikan Wawancara \\
\hline $\begin{array}{l}\text { Kurangnya } \\
\text { perhatian } \\
\text { orang tua } \\
\text { dalam hal } \\
\text { membaca } \\
\text { Alquran }\end{array}$ & Guru PAI & $\begin{array}{l}\text { Di sekolah guru agama hanya bisa memberikan pelajaran } \\
\text { agama hanya } 3 \text { jam pelajaran sedangkan orang tua selalu } \\
\text { punya waktu di rumah untuk mengajarkan dalam membaca } \\
\text { Alquran ataupun usaha lainnya. Selain tanggung jawab guru } \\
\text { agama disekolah, dalam hal membaca Alquran juga } \\
\text { merupakan tanggung jawab orang tua siswa tentunya ya. Jadi } \\
\text { kurangnya perhatian dari orang tua ini dikarenakan memang } \\
\text { orang tua beranggapan anak mereka sudah melakukan hal }\end{array}$ \\
\hline
\end{tabular}


Salma Jihan Utami dan Ahmad Kosasih: Upaya Guru Pendidikan Agama Islam dalam Meningkatkan...

tersebut dengan baik, mereka juga sudah besar dalam
melakukannya sendiri, dan sibuknya orang tua sampai tidak
bisa membagi waktu untuk belajar mengajar membaca
Alquran kepada anaknya.

\section{Simpulan}

Berdasarkan paparan diatas dapat disimpulkan bahwa Upaya guru Pendidikan Agama Islam dalam meningkatkan kemampuan membaca Alquran siswa di SMA Negeri 1 Sungai Penuh adalah dengan cara penerapan metode menyimak, belajar privat (face to face), metode drill, tadarus Alquran dan membaca asmaul husna, membaca surah-surah yang telah dipelajari, membaca surah-surah pendek dalam Alquran, kegiatan jum'at beriman, sabar, telaten, dan guru memberikan motivasi kepada siswa. Faktor pendukung upaya guru Pendidikan Agama Islam dalam meningkatkan kemampuan membaca Alquran siswa di SMA Negeri 1 Sungai Penuh adalah adanya internet, semangat dan motivasi siswa. Sedangkan faktor penghambat adalah beragamnya kemampuan siswa, kejenuhan dalam belajar, terbatasnya waktu dalam pembelajaran Alquran serta kurangnya perhatian dari orang tua dalam hal membaca Alquran.

\section{Referensi}

Asy-Syahida, S. N., \& Rasyid, A. M. (2020). Studi Komparasi Metode Talaqqi dan Metode Tilawati dalam Meningkatkan Kemampuan Membaca Alquran. Jurnal Pendidikan Islam Indonesia, 4(2), 186-191.

Darajat, R., Ginanjar, M. H., \& Wahidin, U. (2019). Upaya Guru Pendidikan Agama Islam (PAI) dan Budi Pekerti Dalam Meningkatkan Prestasi Akademik Peserta Didik Pada Mata Pelajaran PAI dan Budi Pekerti (Studi Di Sman 4 Bogor Tahun Ajaran 2018/2019). Prosa Pai: Prosiding Al Hidayah Pendidikan Agama Islam, 1(2), 75-86.

Frimayanti, Ayu Imelda. (2017). Implementasi Pendidikan Nilai Dalam Pendidikan Agama Islam. Al-Tadzkiyyah: Jurnal Pendidikan Islam, 8(2), 227-247.

Hakim, R. (2014). Pembentukan karakter peserta didik melalui pendidikan berbasis Al-Quran. Jurnal Pendidikan Karakter, (2).

Jull, Muhammad Rifky, (2021), Ulumul Qur'an sebagai Ilmu

Karso, K. (2019, February). Keteladanan Guru Dalam Proses Pendidikan Di Sekolah. In Prosiding Seminar Nasional Program Pascasarjana Universitas PGRI PALEMBANG (Vol. 12, No. 01).

Khasanah, Lailatul. (2019). Peningkatan Kemampuan Membaca Alquran Menggunakan Metode Tartil Bagi Santri di Pondok Pesantren Al Fatimiyyah Al Islamy Desa Adiluhur Kecamatan Jabung Kabupaten Lampung Timu. IAIN Metro

Kustianingrum, A. (2020, September). Peranan Metode Iqro'pada Kemampuan Membaca Alquran Anak. In Seminar Pendidikan Nasional (SENDIKA) (Vol. 2, No. 1).

Nisak, N. M. (2018). Implementasi Kurikulum Pembelajaran Alquran di Sekolah Dasar. Halaqa: Islamic Education Journal, 2(2), 150-164.

Sari, Kurnia Silvi Mustika (2018), Upaya Guru Pendidikan Agama Islam Dalam Meningkatkan Baca Alquran Siswa di SMA Negeri 1 Prambon Ngajuk. IAIN Kediri

Sugiyono. (2008). Metode Penelitian Kuantitatif Kualitatif dan R\&D. Bandung: Alfabeta. 